Review

\title{
Inhibitors of Testosterone Biosynthetic and Metabolic Activation Enzymes
}

\author{
Leping Ye ${ }^{1, *}$, Zhi-Jian Su ${ }^{2}$ and Ren-Shan Ge ${ }^{1,3, *}$ \\ 1 The 2nd Affiliated Hospital, Wenzhou Medical College, Wenzhou, Zhejiang 325000, China \\ 2 Biopharmaceutical Research and Development Center, Jinan University, Guangzhou 510632, \\ China; E-Mail: su_zhijian@126.com (Z.-J.S.) \\ 3 Population Council and Rockefeller University, 1230 York Avenue, New York, NY 10065, USA \\ * Authors to whom correspondence should be addressed; E-Mails: yeleping@163.com (L.Y.); \\ rge@popcbr.rockefeller.edu (R.-S.G.); Tel.: +1-212-327-8754 (R.-S.G.); \\ Fax: +1-212-327-7678 (R.-S.G.).
}

Received: 2 November 2011; in revised form: 21 November 2011 / Accepted: 21 November 2011 / Published: 2 December 2011

\begin{abstract}
The Leydig cells of the testis have the capacity to biosynthesize testosterone from cholesterol. Testosterone and its metabolically activated product dihydrotestosterone are critical for the development of male reproductive system and spermatogenesis. At least four steroidogenic enzymes are involved in testosterone biosynthesis: Cholesterol side chain cleavage enzyme (CYP11A1) for the conversion of cholesterol into pregnenolone within the mitochondria, 3 $\beta$-hydroxysteroid dehydrogenase (HSD3B), for the conversion of pregnenolone into progesterone, 17 $\alpha$-hydroxylase/17,20-lyase (CYP17A1) for the conversion of progesterone into androstenedione and 17 $\beta$-hydroxysteroid dehydrogenase (HSD17B3) for the formation of testosterone from androstenedione. Testosterone is also metabolically activated into more potent androgen dihydrotestosterone by two isoforms $5 \alpha$-reductase 1 (SRD5A1) and 2 (SRD5A2) in Leydig cells and peripheral tissues. Many endocrine disruptors act as antiandrogens via directly inhibiting one or more enzymes for testosterone biosynthesis and metabolic activation. These chemicals include industrial materials (perfluoroalkyl compounds, phthalates, bisphenol A and benzophenone) and pesticides/biocides (methoxychlor, organotins, 1,2-dibromo-3-chloropropane and prochloraz) and plant constituents (genistein and gossypol). This paper reviews these endocrine disruptors targeting steroidogenic enzymes.
\end{abstract}


Keywords: endocrine disruptor; steroidogenic enzymes; steroidogenic inhibitors; Leydig cells; male reproduction

\section{Introduction}

Leydig cells reside in the interstitial compartment of the testis and are responsible for the production of testosterone ( $\mathrm{T}) . \mathrm{T}$ is required for sexual development and testis descent during fetal period [1], the production of sperm in the seminiferous tubules [2] and the maintenance of accessory sex organs [3] and sexual behavior [4] at adulthood. There are two distinct populations of Leydig cells: Fetal and adult Leydig cells. Fetal Leydig cells originate in the fetal testis, and produce T. T is converted by $5 \alpha$-reductase (SRD5A) to more potent androgen dihydrotestosterone (DHT) in some fetal reproductive tissues. T and DHT are required for the development of male reproductive tract and testis descent [1]. Adult Leydig cells develop during puberty and produce $\mathrm{T}$ that is required for maintaining spermatogenesis and male secondary sexual characteristics in adult life. Although Leydig cells only account for about $5 \%$ of all cell types in the testis at adulthood, T produced by them make over $95 \%$ of circulatory T. Chemicals that affect these cells dramatically affect androgen-dependent tissues.

There are reports of increasing incidence of cryptorchidism, hypospadias, testicular cancers and reduced fertility over the past 35 years [5,6]. Concerns have risen about the possible association of exposures to endocrine disruptors (EDs) with reproductive tract anomalies and poor sperm quality [7]. During the past decades, many environmental chemicals are considered to meet the criteria for classification as EDs, including compounds such as plasticizers (phthalates, bisphenol A), surfactants (perfluoroalkyl substances), pesticides (methoxychlor) and plant constituents (genistein and gossypol). Many EDs are classified as antiandrogens, which act against normal function of androgen-related tissues. Antiandrogenic chemicals suppress androgen production in Leydig cells, reduce their numbers, or bind to the androgen receptors (ARs) so as to block activation by androgens. In the present review, we focus on antiandrogenic EDs that directly interfere with $\mathrm{T}$ biosynthetic pathway and/or metabolic activation pathway. We'll discuss the inhibition of EDs on human and rodent (rat and mouse) enzymes.

\section{T Biosynthetic and Metabolic Activation Pathways}

In both fetal and adult Leydig cells, at least four steroidogenic enzymes are involved in $\mathrm{T}$ biosynthesis. $\mathrm{T}$ biosynthesis starts with the substrate cholesterol. The first steroidogenic enzyme is cholesterol side chain cleavage enzyme (CYP11A1) that is located in the inner membrane of the mitochondria [8]. The enzyme catalyzes three sequential reactions from cholesterol into pregnenolone. Pregnenolone diffuses from the mitochondria into the surrounding smooth endoplasmic reticulum, where other three steroidogenic enzymes are located, including 3 $\beta$-hydroxysteroid dehydrogenase (HSD3B), cytochrome P450 17 $\alpha$-hydroxylase/17,20-lyase (CYP17A1) and 17ß-hydroxysteroid dehydrogenase 3 (HSD17B3) [9]. Pregnenolone is finally converted to $\mathrm{T}$ by sequential reactions of these three steroidogenic enzymes. The steroid intermediates differ according to species depending upon whether the $\Delta^{4}$ or $\Delta^{5}$ pathways predominate. The $\Delta^{4}$ pathway (pregnenolone $\rightarrow$ progesterone $\rightarrow$ androstenedione $\rightarrow \mathrm{T}$ ) was first demonstrated in the rat testis [9] (Scheme 1). The $\Delta^{5}$ pathway 
(pregnenolone $\rightarrow$ 17 $\alpha$-hydroxypregnenolone $\rightarrow$ dehydroepiandrosterone $\rightarrow$ androstenedione $\rightarrow \mathrm{T}$ ) is predominant in human testis, although $\Delta^{4}$ pathway also exists [9] (Scheme 1). When $\mathrm{T}$ is formed, $\mathrm{T}$ is metabolized to more potent androgen DHT in Leydig cells or peripheral tissues by several types of $5 \alpha$-reductases (SRD5A1, 2 and 3), particularly SRD5A2 that has high affinity for T [10]. DHT is very critical for male reproductive tract development in male fetus, and the mutation of SRD5A2 gene can cause malformation of male reproductive tract $[11,12]$. An ED that directly inhibits one and/or more of these steroidogenic enzymes leads to lower androgen, thus as an antiandrogen.

Scheme 1. Testosterone biosynthetic and metabolic activation pathways.

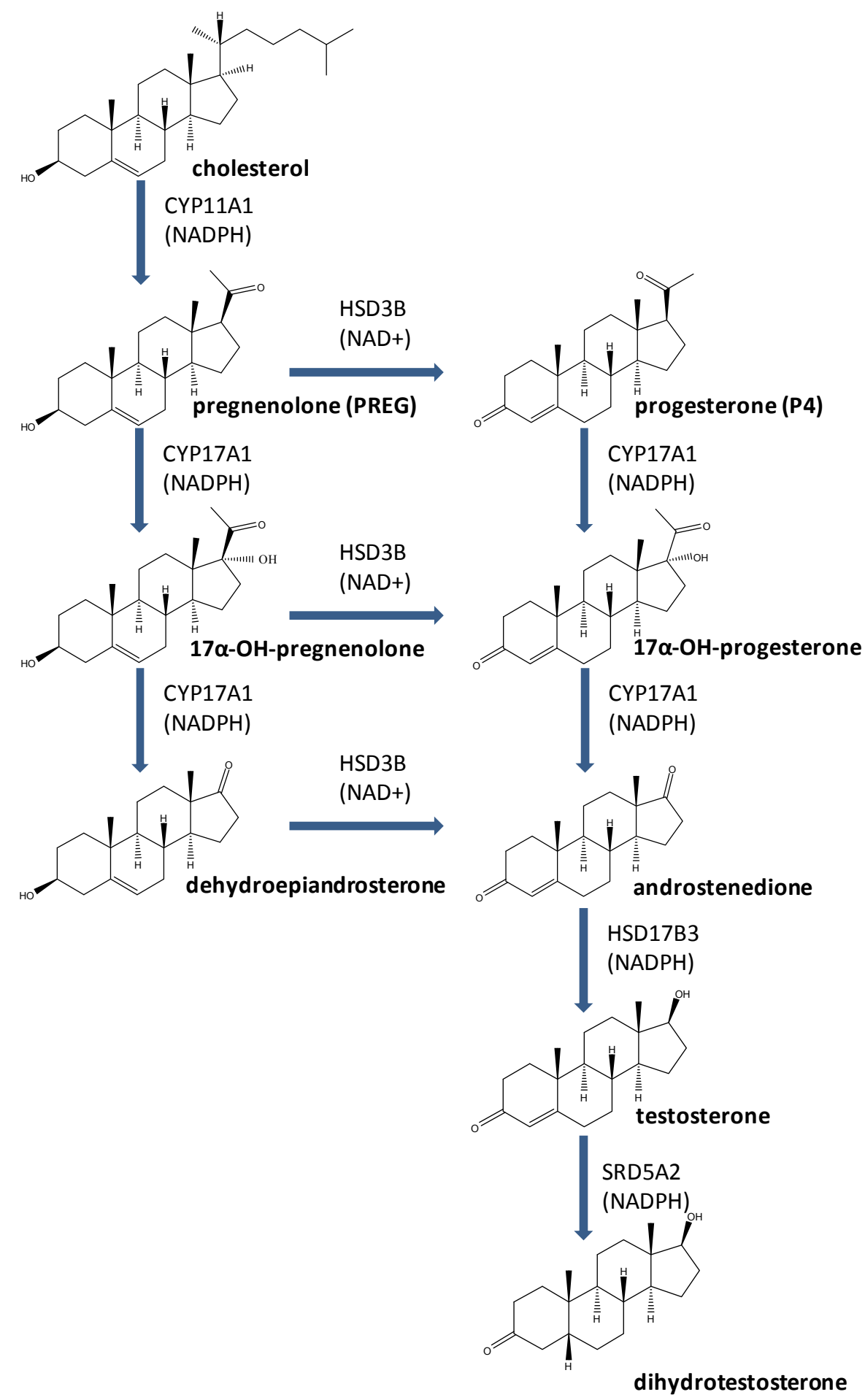




\section{Enzymes for T Biosynthesis and Metabolic Activation}

\subsection{CYP11A1}

CYP11A1 is the first-step enzyme for the conversion of cholesterol to pregnenolone. It is encoded by human CYP11A1 or rat Cypl1a1. The reaction by this enzyme occurs on the inner membrane of the mitochondria. The enzyme catalyzes three sequential reactions with each step using one molecule of cofactor NADPH. NADPH carries the energy, which is delivered by the mitochondrial electron transfer system [9]. During the catalysis, two hydroxyl groups are added to cholesterol (at C20 and C22) followed by cleavage between the added hydroxyl groups, resulting in the formation of pregnenolone [9].

\subsection{HSD $3 B$}

HSD3B is an enzyme to catalyze the conversion of pregnenolone to progesterone in the presence of cofactor $\mathrm{NAD}^{+}$. It is a critical enzyme for the biosynthesis of all biologically active steroids including those in Leydig cells, adrenal, ovary and placenta [13]. HSD3B catalysis has two steps, catalyzing dehydrogenation and isomerization of a double bond in the steroid molecule, with the first dehydrogenase step being rate-limiting. There are several isoforms, with some expressed in non-classic steroidogenic tissues [9]. Two human $H S D 3 B$ genes have been identified with $81.9 \%$ identity. Human $H S D 3 B 1$ is primarily present in placenta, while $H S D 3 B 2$ is predominantly expressed in adrenal and Leydig cells. Therefore, the review focuses on human HSD3B2 activity. In the patients with $H S D 3 B 2$ mutation $[14,15]$, pregnenolone is not converted into progesterone in the male. In this disorder, males show varying degrees of feminization, including the development of a vagina and breast at puberty, because serum T levels are very low. Four isoforms of HSD3B in the rat have been identified [9], with each of these isoforms is the product of a distinct gene [9]. In rat Leydig cells, HSD3B1 (encoded by $H s d 3 b 1$ ) is the primary enzyme for formation of progesterone [16].

\section{3. $C Y P 17 A 1$}

CYP17A1 is encoded by CYP17A1 (human) or Cyp17al (rat), one enzyme with two activities. Unlike CYP11A1, which is found in the mitochondria, CYP17A1 is found in the smooth endoplasmic reticulum (SER) of Leydig cells and catalyzes two functional oxidase reactions of progesterone to $17 \alpha$-hydroxyprogesterone by $17 \alpha$-hydroxylase, and further $17 \alpha$-hydroxyprogesterone into androstenedione by 17,20-lyase [17]. Each reaction requires cofactor NADPH [9]. The microsomal electron transfer protein cytochrome P450 oxidoreductase transfers electrons [9]. CYP17A1 catalyzes both pregnenolone and progesterone (Figure 1). Although CYP17A1 catalyzes both hydroxylation and lysis reactions, there are species-dependent differences in the utilization of either $17 \alpha$-hydroxypregnenolone $(\Delta 5)$ or $17 \alpha$-hydroxyprogesterone $(\Delta 4)$ as substrate for the lyase reaction. The human CYP17A1 uses $17 \alpha$-hydroxypregnenolone as the preferential substrate to yield dehydroepiandrosterone, whereas rat enzyme utilizes $17 \alpha$-hydroxyprogesterone as the substrate to yield androstenedione. A mutation of CYP17A1 alters the conversion of progesterone to androstenedione in the male, leading to defective masculinization that can range from partial to complete pseudohermaphroditism and breast enlargement $[18,19]$. 


\subsection{HSD17B3}

There are over fourteen 17ß-hydroxysteroid dehydrogenase isoforms [16]. Only HSD17B3 is located in Leydig cells for the final conversion of androstenedione into T [20]. HSD17B3 is encoded by human $H S D 17 B 3$ or rat $H s d 17 b 3$. HSD17B3 requires NADPH as its cofactor. The production of $\mathrm{T}$ is considered an end-product. The mutation of $H S D 17 B 3$ causes various phenotypes including pseudohermaphroditism with very low circulating $\mathrm{T}$ in males [21,22].

\subsection{SRD5A2}

SRD5A2 is encoded by SRD5A2 (human) and $\operatorname{Srd5a2}$ (rat). To date, three distinct SRD5As have been characterized. Human genes encode type 1 (SRD5A1), 2 (SRD5A2) and 3 (SRD5A3) 5 $\alpha$-reductases, which catalyze the conversion of T into DHT [23-25]. Rat genes have the similar designation (Srd5al, Srd5a2 and Srd5a3). The SRD5A uses NADPH as a cofactor [20,26]. A cDNA encoding human SRD5A1 was first cloned [27]. So far, no clear mutation of SRD5A1 has been found to be associated with any human diseases. However, when human SRD5A2 was cloned, the mutation of this enzyme was found to be associated with male pseudohermaphroditism [28]. SRD5A2 gene is localized to human chromosome 2 [29]. Recently, human $S R D 5 A 3$ was identified after a genome wide screening of hormone-refractory prostate cancer cDNAs [30]. SRD5A3 is found not only to catalyze the formation of DHT but also to convert polyprenol to dolichol, and its mutation causes congenital glycosylation disorder, which does not affect reproduction [25]. Therefore, only SRD5A2 is associated with the development of male reproductive tract.

\section{EDs with Direct Inhibition on Enzymes for T Biosynthesis and Metabolic Activation}

Environmental chemicals can directly alter the $\mathrm{T}$ biosynthetic or the metabolic activation pathways. Altering one or more steps in the steroidogenesis has the potential to cause reproductive toxicity, including abnormal reproductive tract, diminished fertility and hypogonadism [31]. We list examples of chemicals that directly alter key steps in the steroidogenic pathway (Table 1). The spectrum of inhibitors has been expanded to many categories of chemicals including industrial materials (perfluoroalkyl substances, phthalates, bisphenol A), insecticides/biocides (methoxychlor and prochloraz) and plant constituents (isoflavone and gossypol). Although some other toxicants (like PCB congeners) that also interfere with steroidogenic machinery, they are not included in this review because none were reported to directly inhibit steroidogenic enzymes.

Table 1. Inhibitors of enzymes for testosterone biosynthesis and metabolic activation.

\begin{tabular}{cccc}
\hline Enzyme & Chemicals & Use & Mode of inhibition \\
\hline \multirow{2}{*}{ CYP11A1 } & Enzymes for Testosterone Biosynthesis & \\
& Methoxychlor \& HPTE & Insecticide & Non-competitive \\
& Gossypol & Plant constituent & Mixed type \\
& Lindane & Insecticide & Unknown \\
\hline
\end{tabular}


Table 1. Cont.

\begin{tabular}{|c|c|c|c|}
\hline Enzyme & Chemicals & Use & Mode of inhibition \\
\hline \multirow[t]{9}{*}{ HSD3B } & Perfluorooctane sulfonate & Surfactant & Competitive \\
\hline & Perfluorooctane acid & Surfactant & Competitive \\
\hline & Phthalates & Plasticizers & Competitive \\
\hline & Bisphenol A & Plasticizer & Competitive \\
\hline & Methoxychlor \& HPTE & Insecticide & Non-competitive \\
\hline & Triphenyltin & Biocide & Unknown \\
\hline & Tributyltin & Biocide & Unknown \\
\hline & Genistein & Plant constituent & Competitive \\
\hline & Gossypol & Plant constituent & Competitive \\
\hline \multirow[t]{6}{*}{ CYP17A1 } & Bisphenol A & Plasticizer & Competitive \\
\hline & Triphenyltin & Biocide & Unknown \\
\hline & Tributyltin & Biocide & Unknown \\
\hline & 1,2-Dibromo-3-chloropropane & Insecticide & Unknown \\
\hline & Prochloraz & Biocide & Unknown \\
\hline & Gossypol & Plant constituent & Unknown \\
\hline \multirow[t]{10}{*}{ HSD17B3 } & Perfluorooctane sulfonate & Surfactant & Non-competitive \\
\hline & Perfluorooctane acid & Surfactant & Non-competitive \\
\hline & Phthalates & Plasticizers & Unknown \\
\hline & Bisphenol A & Plasticizer & Competitive \\
\hline & Benzophenones & UV blocker & Unknown \\
\hline & Methoxychlor \& HPTE & Insecticide & Non-competitive \\
\hline & Triphenyltin & Biocide & Unknown \\
\hline & Tributyltin & Biocide & Unknown \\
\hline & Gossypol & Plant constituent & Competitive \\
\hline & Enzyme for Testostero & e Metabolic Activ & \\
\hline \multirow[t]{4}{*}{ SRD5A2 } & Triphenyltin & Biocide & Non-competitive \\
\hline & Tributyltin & Biocide & Non-competitive \\
\hline & Genistein & Food constituent & Unknown \\
\hline & Gossypol & Plant constituent & Unknown \\
\hline
\end{tabular}

HPTE: 2,2-bis(p-hydroxyphenyl)-1,1,1-trichloroethane.

\subsection{Industrial Materials}

\subsubsection{Perfluoroalkyl Substance (PFASs)}

PFASs are polyfluoroalkyl compounds that are widely used for industrial and consumer products because of their unique properties of extreme stability and surface activity [32]. These chemicals are used as surfactants, adhesives and insecticides such as coatings of textiles, paper and upholstery and as reaction additives in various processes [33-35]. These chemicals are persistent in the environment because they are not broken down chemically and have become widespread in the environment and accumulated in wildlife and humans. Some PFASs, including perfluorooctane sulfonate (PFOS, 8 carbons +1 sulfur), perfluorooctane acid (PFOA, 8 carbons) and perfluorohexane sulfonate (PFHxS, 6 carbons +1 sulfur) have been classified as persistent organic pollutants in the general population rates are over 4 years in humans [36]. The levels of PFOS, PFOA and PFHxS in the blood of human 
subjects are related to the exposure level and duration. The serum levels of PFOS, PFOA and PFHxS in the United States in 2006 are about 14.7, 3.4 and $1.5 \mathrm{ng} / \mathrm{mL}$, respectively [37]. A short carbon chain perfluorobutane sulfonate (PFBS, 4 carbons +1 sulfur) has been introduced recently to replace PFOA, PFOS and PFHxS compounds. The serum elimination of PFBS is expected to be more rapid than that of PFOA or PFOS [38], thus becoming less accumulation in human bodies.

There is growing evidence that PFASs may act as EDs, interfering with the reproductive system in males. Workers in $3 \mathrm{M}$ in Cottage Groove of the United States that produced PFOA had higher serum level of PFOA and decreased serum T concentrations [39,40]. Laboratory animal studies also showed that rats exposed to PFOA and related chemicals had lower T levels [41,42]. One of the mechanisms by PFASs may be caused by their direct inhibition on some $\mathrm{T}$ biosynthetic enzymes. Apparently, PFOS and PFOA directly inhibit rat Leydig cell HSD3B. Structure activity response analysis of the inhibitory actions on rat testicular HSD3B by PFASs showed that PFASs had clear structure activity response depending on the length of carbon plus sulfur chain, with inhibitory potency of PFOS $\left(\mathrm{IC}_{50}=1.3 \mu \mathrm{M}\right)>$ PFOA $\left(\mathrm{IC}_{50}=53.2 \mu \mathrm{M}\right)>$ PFHxS (no inhibition at $\left.250 \mu \mathrm{M}\right)=$ PFBS (no inhibition at $250 \mu \mathrm{M})$ [32]. The mode of the inhibition on rat HSD3B is competitive against substrate pregnenolone [32]. Surprisingly, PFASs have almost no inhibitory effects on human testicular HSD3B activity [32]. In the contrast, PFOS is a very potent human testicular HSD17B3 inhibitor. The potencies are PFOS $\left(\mathrm{IC}_{50}=6.0 \mu \mathrm{M}\right)>$ PFOA $\left(\mathrm{IC}_{50}=127.6 \mu \mathrm{M}\right)>$ PFHxS $($ no inhibition at $250 \mu \mathrm{M})=$ PFBS (no inhibition at $250 \mu \mathrm{M}$ ) [32]. PFOS shows a non-competitive inhibition of human HSD17B3 [32]. Of these PFASs, only PFOA potently inhibits rat Leydig cell HSD17B3 with $\mathrm{IC}_{50}$ value of $17 \mu \mathrm{M}$ [43]. The inhibition of HSD3B and HSD17B3 activities in rat Leydig cells clearly leads to the decrease of $\mathrm{T}$ production in Leydig cells [43]. No reports have been shown concerning the effects of PFASs on CYP11A1, CYP17A1 and SRD5A2 activities.

\subsubsection{Phthalates}

Phthalates are synthetic compounds, which are widely used as plasticizers and solvents in a variety of polyvinyl chloride consumer products [44]. Phthalates are not chemically bound to polyvinyl chloride and easily leached out. The leached phthalates in the environment are significant because phthalates usually make up to $40 \%$ of the volume of the plastics [45]. Worldwide, manufacturers produce an estimated one billion pounds of phthalates per year [46]. Dozens of phthalates are manufactured and their difference depends on length carbon chain in the alcohol moiety. For example, dimethyl phthalate (DMP) has one carbon, and di-n-butyl phthalates (DBP) has four carbons in the alcohol moiety. The most abundant are diethylhexyl phthalate (DEHP) and DBP [47]. When absorbed into human body, phthalate diesters are rapidly converted into monoester metabolites [48]. Some monoester metabolites are believed to be more potent than their parent compounds for their toxicity. For example, the monoethylhexyl phthalate (MEHP), the metabolite of DEHP, has been found to be 10 times more potent than DEHP for its toxicity [49].

Phthalates have been classified as antiandrogens. Apparently, phthalates act not via blocking the androgen receptor, since they do not bind to androgen receptor [47]. In vivo studies using animal models have shown that DEHP and DBP indeed are antiandrogens, causing various androgen-deficient reproductive malformations, including hypospadia and indecent testis after birth, when male fetus are 
exposed to phthalates during gestation [50-55]. Epidemiological studies also claim that exposure to phthalates may be linked to abnormal reproductive development in human male embryos [56-58]. Although many mechanisms account for the reduction of $\mathrm{T}$ after in vivo or in vitro exposure to phthalates $[47,52,53,56,57]$, the direct inhibitory effects of phthalates on some $\mathrm{T}$ biosynthetic enzymes may also be involved. It was found that the treatment of dipentyl phthalate can cause a significant decrease of CYP17A1 activity [59]. We also demonstrate that dipropyl phthalate, DBP, dipentyl phthalate, dicyclohexyl phthalate, benzyloctyl phthalate and butylbenzyl phthalate significantly inhibit both human and rat testicular HSD3B and HSD17B3 activities at concentrations of $100 \mu \mathrm{M}$ (unpublished data). In vitro, the DBP metabolite monobutyl phthalate does not appear to inhibit 22-OH-cholesterol-induced $\mathrm{T}$ production in the fetal rat testis, indicating monobutyl phthalate does not inhibit CYP11A1 activity [60]. DEHP is not the SRD5A inhibitor either [61].

\subsubsection{Bisphenol A (BPA)}

BPA is a synthetic compound that is used primarily in the manufacture of polycarbonate plastic and epoxy resins, and as a non-polymer additive to other plastics. Sources of human exposure to BPA include indoor air, dust ingestion and contamination of foods [62]. Various studies have demonstrated significant exposure to humans with $95 \%$ of detection in human urine samples [63-65]. There is clear sex differences regarding to serum BPA levels, which are significantly higher in normal men $(1.49 \mathrm{ng} / \mathrm{mL})$ compared to those of women $(0.64 \mathrm{ng} / \mathrm{mL})$. This gender difference in serum BPA levels are possibly due to difference in the androgen-related metabolism of BPA [66].

Many studies propose BPA as an estrogenic compound because it weakly binds to estrogen receptor [67,68]. BPA is also an antiandrogen, as it binds to human androgen receptor and blocks DHT-induced androgen receptor transcription activity [67,68]. Its antiandrogenic potency is comparable to the androgen receptor antagonist flutamide $[67,68]$. Both in vivo and in vitro exposures to BPA in rodents caused significant decreases of $\mathrm{T}$ production $[69,70]$. The inhibition of $\mathrm{T}$ production in rat Leydig cells has been shown to be associated with its direct inhibition on $\mathrm{T}$ biosynthetic enzyme activities. Although BPA has no direct inhibitory effects on CYP11A1 activity [71], it inhibits other three $\mathrm{T}$ biosynthetic enzymes by various degrees [72]. BPA inhibits human and rat testicular HSD3B with $\mathrm{IC}_{50} \mathrm{~S}$ of 7.9 and $26.5 \mu \mathrm{M}$, and human and rat CYP17A1 activities with $\mathrm{IC}_{50} \mathrm{~S}$ of 18.9 and $64.6 \mu \mathrm{M}$, respectively. BPA is also a weak human and rat HSD17B3 inhibitor with $\mathrm{IC}_{50} \mathrm{~S}$ about $100 \mu \mathrm{M}$ [72]. BPA is a competitive inhibitor for both HSD3B [72] and CYP17A1 [72,73] against each steroid substrate, possibly because it has very similar chemical structure to steroid substrates.

\subsubsection{Benzophenone (BP)}

Benzophenones are the synthesized chemicals that block UV and are widely used in inks, imaging, and clear coatings in the printing industry. BPs are exposed because they migrate into food from packing [74]. Many BPs may have antiandrogenic activities. Of nine BPs (1-8 and 12) tested, BP-1 is the most potent inhibitor of human HSD17B3 activities with $\mathrm{IC}_{50}$ of $1 \mu \mathrm{M}$, while others have $\mathrm{IC}_{50} \mathrm{~S}$ around 47-111 $\mu \mathrm{M}$ [75]. Apparently, the inhibition of BP-1 on human HSD17B3 activity is selective, since it inhibits HSD17B1 and HSD17B2 activities with $\mathrm{IC}_{50}$ over $20 \mu \mathrm{M}$ and has no inhibition on 
HSD17B5 activity [75]. Rodent models also show BP-1 significantly inhibits T production in mouse and rat testes [75].

\subsection{Insecticides and Fungicides}

\subsubsection{Methoxychlor (MXC)}

The organochlorine pesticide MXC is developed as a replacement for the banned pesticide 2,2-bis( $p$-chlorophenyl)-1,1,1-trichloroethane (DDT) and is widely used. MXC is a known ED to cause the reduction of luteinizing hormone ( $\mathrm{LH}$ )-stimulated $\mathrm{T}$ production in rodent Leydig cells [76-78]. Some effects of MXC is believed to be mediated by its bioactive metabolite, 2,2-bis( -hydroxyphenyl)1,1,1-trichloroethane (HPTE) [77]. Both MXC and HPTE have estrogenic activities via binding to estrogen receptor [79]. MXC is also an antiandrogen. The androgenic effects of MXC and its metabolite HPTE are mediated via direct inhibition of $\mathrm{T}$ biosynthetic enzymes. MXC and HPTE directly inhibit $\mathrm{T}$ production in rat Leydig cells via inhibiting CYP11A1 activities starting at $100 \mathrm{nM}$ [80]. Using purified pig CYP11A1, $\left[{ }^{14} \mathrm{C}\right] \mathrm{MXC}$ was found to irreversibly bind to CYP11A1 and abolish the enzyme activity [81], suggesting that $\mathrm{MXC}$ is non-competitive inhibitor of CYP11A1. MXC also inhibits human and rat testicular HSD3B activities, with $\mathrm{IC}_{50} \mathrm{~s}$ of $53.2 \mu \mathrm{M}$ (human) and $46.15 \mu \mathrm{M}$ (rat). It seems that HPTE is more potent than $\mathrm{MXC}$, because it has $\mathrm{IC}_{50} \mathrm{~s}$ of $8.2 \mu \mathrm{M}$ (human) and $13.8 \mu \mathrm{M}$ (rat) for HSD3B activity. The mode of MXC and HPTE on HSD3B activity is non-competitive against the substrate pregnenolone. At the concentration as high as $100 \mu \mathrm{M}, \mathrm{MXC}$ does not have inhibitory effects on human and rat HSD17B3 activities, while HPTE significantly inhibits human and rat HSD17B3 activities with $\mathrm{IC}_{50} \mathrm{~s}$ of $12.1 \mu \mathrm{M}$ (human) and $32.0 \mu \mathrm{M}$ (rat), suggesting that $\mathrm{MXC}$ is metabolically activated into HPTE to inhibit HSD17B3 activity.

\subsubsection{Organotins}

Organotins are the organometallic compounds and have been widely used as antifouling biocides for ships and fishing nets, agricultural fungicides and rodent repellents [82]. Their widespread uses have resulted in the release of increasing amounts of organotins into the environment. Organotins have been shown to be antiandrogens. For example, tributyltin causes serious defects in testicular development and function in vivo [68]. Studies have shown that organotins directly inhibited many $\mathrm{T}$ biosynthetic and metabolizing enzymes. Organotins tributyltin and triphenyltin inhibit pig CYP17A1 activities with $\mathrm{IC}_{50} \mathrm{~S}$ of about $117 \mu \mathrm{M}$ [83]. Tributyltin inhibits rat CYP17A1 with $\mathrm{IC}_{50}$ of about $50 \mu \mathrm{M}$ [83]. Tributyltin is a primarily competitive inhibitor of rat testicular HSD3B activity with Ki of $2.4 \mu \mathrm{M}$ [84]. Triphenyltin and tributyltin inhibited HSD17B3 activities from pig Leydig cells with $\mathrm{IC}_{50} \mathrm{~s}$ of 48 and $148 \mathrm{nM}$, respectively [83]. Lo et al. [85] investigated the in vitro effects of triphenyltin on human T biosynthetic and metabolizing enzymes including HSD3B2, HSD17B3 and SRD5A2 activities. The $\mathrm{IC}_{50} \mathrm{~s}$ of inhibiting HSD3B2, HSD17B3 and SRD5A2 are 4.0, 4.2 and $0.95 \mu \mathrm{M}$, respectively [85]. The inhibition of SRD5A2 activity may be mediated by the interaction of triphenyltin with critical cysteine residues of the enzymes [85]. The T metabolism is also performed on effects of tributyltin chloride, which inhibits human SRD5A1 and SRD5A2 with $\mathrm{IC}_{50}$ of 19.9 and $10.8 \mu \mathrm{M}$, respectively [86]. Both isoforms are not affected by tetrabutyltin or monobutyltin indicating that at least two butyl groups 
bound to the positively charged Sn are required for the interaction of butyltin with the enzymes [86]. The inhibition of tributyltin on SRD5A1 is competitive while that on SRD5A2 activity is irreversible [86].

\subsubsection{1,2-Dibromo-3-chloropropane (DBCP)}

DBCP is a pesticide, which has been used for over 20 years to control plant worms. It was banned by the US Environmental Protection Agency in 1977, because it was shown to be antiandrogen to cause infertility in male workers [87-89]. DBCP-exposed males may develop oligospermia and hypogonadism, but the cause is reversible [90-92]. The route of exposure seems to be a critical factor for the testicular toxicity of DBCP [87-89,93-96]. Although, many studies concluded that Leydig cells in the testis were secondary targets for DBCP toxicity, Kelce et al. [97] demonstrated that DBCP also had a direct inhibitory effect on the 17 $\alpha$-hydroxylase activity of CYP17A1 but not the 17,20-lyase activity [97].

\subsubsection{Lindane}

Lindane is an organochlorine insecticide. Lindane was found in the human and rat testis after exposure $[98,99]$. It has been shown that lindane adversely affected male reproductive function in rats after in utero exposure and therefore it is classified as an antiandrogen [100-104]. Lindane inhibited human chorionic gonadotropin-stimulated T production by rat Leydig cells [101,102], suggesting that the compound might affect testicular steroidogenesis [105]. Indeed, lindane inhibits mouse CYP11A1 activity [106].

\subsubsection{Prochloraz}

Prochloraz is an imidazole fungicide widely used for horticulture and agriculture. The action of imidazoles (e.g., ketoconazole) used as fungicides is based on the inhibition of the cytochrome P450-dependent 14 $\alpha$-demethylase activity that catalyzes the conversion of lanosterol to ergosterol, an essential component of fungal cell membranes [107]. Prochloraz is classified as an antiandrogen. Maternal exposure to prochloraz caused malformation of male reproductive tracts in fetal male rats and reduced steroidogenesis in the testis [108]. Prochloraz also decreased serum T levels and delayed puberty in males during the pubertal exposure [109]. This may be contributed by the direct inhibition of prochloraz on some T biosynthetic enzymes. Indeed, prochloraz inhibited rat testicular CYP17A1 activity with $\mathrm{Ki}$ around $1 \mu \mathrm{M}$ [108]. Using human adrenal H295R cells, prochloraz also concentrationdependently inhibited human CYP17A1 activity [110], and the inhibition was more selective since it did not inhibit another CYP enzyme CYP11B1, which is required for glucocorticoid biosynthesis [110].

\subsection{Plant Active Constituents}

\subsubsection{Isoflavone (Genistein)}

Genistein, a soy isoflavone, is classified as a phytoestrogen. It is widely distributed in human and animal diet. It possesses a structure similar to estrogen $17 \beta$-estradiol and can either mimic or antagonize estrogen [111]. The highest amount of flavonoids has been found in soybeans and soy food [112]. Several studies have reported on an influence by isoflavones on Leydig cell function by decreasing $\mathrm{T}$ 
production [113]. Although the exact mechanisms of genistein on T production are not clear, the direct inhibitions of some $\mathrm{T}$ biosynthetic enzyme activities may account for. Genistein is a potent competitive inhibitor of human and rat testicular HSD3B activity with the $\mathrm{IC}_{50}$ of $0.09 \mu \mathrm{M}$ (human) and $0.64 \mu \mathrm{M}$ (rat) [114]. Another isoflavone equol is far less potent, and it inhibited human testicular HSD3B by $42 \%$ at $100 \mu \mathrm{M}$. In contrast to its potent inhibition of testicular HSD3B activity, genistein had less potent inhibition on human and rat HSD17B3, and the $\mathrm{IC}_{50} \mathrm{~S}$ are $\geq 100 \mu \mathrm{M}$ [114]. Genistein inhibited human SRD5A2 activity too, and it is a much potent inhibitor of SRD5A2 than SRD5A1 [115]. Given the increasing intake of soy-based food products and their potential effect on blood androgen level, these findings are greatly relevant to public health.

\subsubsection{Gossypol}

Gossypol is a yellowish polyphenolic compound isolated from cotton seeds, and it was once tested as a very effective male contraceptive in China [116]. Because of its possible side effects such as hypokalemia and irreversible suppression of spermatogenesis, gossypol would not be acceptable as a male contraceptive, after evaluation by World Health Organization [117]. The exposure to gossypol could be from ingestion of cotton seed oils and materials. Food and animal agricultural industries must manage cotton-derivative product levels to avoid gossypol toxicity.

Gossypol has direct inhibition on some steroidogenic enzymes. Gossypol at 17-34 $\mu \mathrm{M}$ significantly inhibited the conversion of 25-hydroxycholesterol into pregnenolone and pregnenolone into progesterone in bovine luteal cells, suggesting that gossypol inhibits CYP11A1 and HSD3B activities [118]. Indeed, gossypol inhibited CYP11A1 from bovine adrenal mitochondria at $30 \mu \mathrm{M}$ [119]. Gossypol is the very potent inhibitor of human and rat testicular HSD3B activities with $\mathrm{IC}_{50} \mathrm{~S}$ of $3-5 \mu \mathrm{M}$ for human and $0.2 \mu \mathrm{M}$ for rat's enzyme [120]. Gossypol potently inhibited human and rat HSD17B3 with clear enantiomer-specific differences. (-)-Gossypol inhibited human and rat HSD17B3 activities with $\mathrm{IC}_{50} \mathrm{~S}$ of 0.36 and $3.43 \mu \mathrm{M}$, respectively, while the (+)-gossypol is slightly less potent and inhibited human and rat $\mathrm{HSD} 17 \mathrm{~B} 3$ activities with $\mathrm{IC}_{50}$ of $1.13 \mu \mathrm{M}$ and $10.93 \mu \mathrm{M}$, respectively [120]. Gossypol inhibited T metabolizing enzymes SRD5A, and its inhibitory effect is more potent for SRD5A1 than SRD5A2 activity [115].

\section{Summary and Conclusions}

Leydig cells of the testis are responsible for the biosynthesis and secretion of androgens, which is critical for developmental and reproductive function in the male. Disruption of $\mathrm{T}$ biosynthesis and metabolic activation by EDs can cause sexual dysfunction, infertility or sterility. Many EDs were found to act directly on enzyme activity in Leydig cells. The impaired function of Leydig cells is displayed by a decrease in $\mathrm{T}$ production as a consequence of the suppressed CYP11A1, CYP17A1, HSD3B and HSD17B3 activities. The direct inhibition on SRD5A2 may also contribute to the abnormal development of male reproductive tract. However, our knowledge on the different EDs for disruption of particular target molecules involved in steroidogenesis is still limited, further studies are warranted to assess the effects of EDs on male fertility. 


\section{Acknowledgements}

We thank Chantal M. Sottas for her critical comments. Supported in part by NSFC 81102150 to L.Y., NSFC 30871434 to R.-S.G., Science and Technology Planning Project of Guangdong Province 2010B05070000 to R.-S.G.; Fundamental Research Funds for the Central Universities 21611508 to Z.-J.S.

\section{References and Notes}

1. Huhtaniemi, I.; Pelliniemi, L.J. Fetal Leydig cells: Cellular origin, morphology, life span, and special functional features. Proc. Soc. Exp. Biol. Med. 1992, 201, 125-140.

2. Awoniyi, C.A.; Santulli, R.; Sprando, R.L.; Ewing, L.L.; Zirkin, B.R. Restoration of advanced spermatogenic cells in the experimentally regressed rat testis: Quantitative relationship to testosterone concentration within the testis. Endocrinology 1989, 124, 1217-1223.

3. Fujii, T. Roles of age and androgen in the regulation of sex accessory organs. Adv. Sex Horm. Res. 1977, 3, 103-137.

4. Wilson, J.D. Prospects for research for disorders of the endocrine system. J. Am. Med. Assoc. 2001, 285, 624-627.

5. Skakkebaek, N.E.; Rajpert-De Meyts, E.; Main, K.M. Testicular dysgenesis syndrome: An increasingly common developmental disorder with environmental aspects. Hum. Reprod. 2001, 16, 972-978.

6. Carlsen, E.; Swan, S.H.; Petersen, J.H.; Skakkebaek, N.E. Longitudinal changes in semen parameters in young Danish men from the Copenhagen area. Hum. Reprod. 2005, 20, 942-949.

7. Moline, J.M.; Golden, A.L.; Bar-Chama, N.; Smith, E.; Rauch, M.E.; Chapin, R.E.; Perreault, S.D.; Schrader, S.M.; Suk, W.A.; Landrigan, P.J. Exposure to hazardous substances and male reproductive health: A research framework. Environ. Health Persp. 2000, 108, 803-813.

8. Ge, R.S.; Hardy, M.P. Regulation of Leydig cells during pubertal development. In The Leydig Cell in Health and Disease; Payne, A.H., Hardy, M.P., Eds.; Humana Press: New York, NY, USA, 2007; pp. 55-70.

9. Payne, A.H.; O'Shaughnessy, P.J. Structure, function and regulation of steroidogenic enzymes in the Leydig cell. In The Leydig Cell; Payne, A.H., Hardy, M.P., Russell, L.D., Eds.; Cache River Press: Vienna, IL, USA, 1996; pp. 259-286.

10. Eik-Nes, K.B. Production and secretion of 5-reduced testosterone (DHT) by male reproductive organs. J. Steroid Biochem. 1975, 6, 337-339.

11. Samtani, R.; Bajpai, M.; Ghosh, P.K.; Saraswathy, K.N. SRD5A2 gene mutations-A populationbased review. Pediatr. Endocrinol. Rev. 2010, 8, 34-40.

12. Maimoun, L.; Philibert, P.; Cammas, B.; Audran, F.; Bouchard, P.; Fenichel, P.; Cartigny, M.; Pienkowski, C.; Polak, M.; Skordis, N.; et al. Phenotypical, biological, and molecular heterogeneity of 5alpha-reductase deficiency: An extensive international experience of 55 patients. J. Clin. Endocr. Metab. 2011, 96, 296-307.

13. Tang, P.Z.; Tsai-Morris, C.H.; Dufau, M.L. Regulation of 3beta-hydroxysteroid dehydrogenase in gonadotropin-induced steroidogenic desensitization of Leydig cells. Endocrinology 1998, 139, 4496-4505. 
14. Mendonca, B.B.; Bloise, W.; Arnhold, I.J.; Batista, M.C.; Toledo, S.P.; Drummond, M.C.; Nicolau, W.; Mattar, E. Male pseudohermaphroditism due to nonsalt-losing 3beta-hydroxysteroid dehydrogenase deficiency: Gender role change and absence of gynecomastia at puberty. J. Steroid Biochem. 1987, 28, 669-675.

15. Lutfallah, C.; Wang, W.; Mason, J.I.; Chang, Y.T.; Haider, A.; Rich, B.; Castro-Magana, M.; Copeland, K.C.; David, R.; Pang, S. Newly proposed hormonal criteria via genotypic proof for type II 3beta-hydroxysteroid dehydrogenase deficiency. J. Clin. Endocr. Metab. 2002, 87, 2611-2622.

16. Penning, T.M. Molecular endocrinology of hydroxysteroid dehydrogenases. Endocr. Rev. 1997, 18, 281-305.

17. Gilep, A.A.; Sushko, T.A.; Usanov, S.A. At the crossroads of steroid hormone biosynthesis: The role, substrate specificity and evolutionary development of CYP17. Biochim. Biophys. Acta 2011, 1814, 200-209.

18. Geller, D.H.; Auchus, R.J.; Mendonca, B.B.; Miller, W.L. The genetic and functional basis of isolated 17,20-lyase deficiency. Nat. Genet. 1997, 17, 201-205.

19. Jones, K.L.; Freidenberg, G.R.; Buchta, R.; Derenoncourt, A. Male pseudohermaphroditism resulting from 17 alpha-monooxygenase (P-450C17) deficiency in two unrelated Guamanians. Am. J. Dis. Child. 1992, 146, 592-595.

20. Ge, R.S.; Hardy, M.P. Variation in the end products of androgen biosynthesis and metabolism during postnatal differentiation of rat Leydig cells. Endocrinology 1998, 139, 3787-3795.

21. Andersson, S.; Geissler, W.M.; Wu, L.; Davis, D.L.; Grumbach, M.M.; New, M.I.; Schwarz, H.P.; Blethen, S.L.; Mendonca, B.B.; Bloise, W.; et al. Molecular genetics and pathophysiology of 17beta-hydroxysteroid dehydrogenase 3 deficiency. J. Clin. Endocr. Metab. 1996, 81, 130-136.

22. Rosler, A.; Silverstein, S.; Abeliovich, D.A. (R80Q) mutation in 17 beta-hydroxysteroid dehydrogenase type 3 gene among Arabs of Israel is associated with pseudohermaphroditism in males and normal asymptomatic females. J. Clin. Endocr. Metab. 1996, 81, 1827-1831.

23. Jenkins, E.P.; Hsieh, C.L.; Milatovich, A.; Normington, K.; Berman, D.M.; Francke, U.; Russell, D.W. Characterization and chromosomal mapping of a human steroid 5 alpha-reductase gene and pseudogene and mapping of the mouse homologue. Genomics 1991, 11, 1102-1112.

24. Thigpen, A.E.; Davis, D.L.; Milatovich, A.; Mendonca, B.B.; Imperato-McGinley, J.; Griffin, J.E.; Francke, U.; Wilson, J.D.; Russell, D.W. Molecular genetics of steroid 5 alpha-reductase 2 deficiency. J. Clin. Invest. 1992, 90, 799-809.

25. Cantagrel, V.; Lefeber, D.J.; Ng, B.G.; Guan, Z.; Silhavy, J.L.; Bielas, S.L.; Lehle, L.; Hombauer, H.; Adamowicz, M.; Swiezewska, E.; et al. SRD5A3 is required for converting polyprenol to dolichol and is mutated in a congenital glycosylation disorder. Cell 2010, 142, 203-217.

26. Wilson, J.D.; Goldstein, J.L. Classification of hereditary disorders of sexual development. Birth Defects Orig. Artic. Ser. 1975, 11, 1-16.

27. Andersson, S.; Russell, D.W. Structural and biochemical properties of cloned and expressed human and rat steroid 5 alpha-reductases. Proc. Natl. Acad. Sci. USA 1990, 87, 3640-3644.

28. Andersson, S.; Berman, D.M.; Jenkins, E.P.; Russell, D.W. Deletion of steroid 5 alpha-reductase 2 gene in male pseudohermaphroditism. Nature 1991, 354, 159-161.

29. Thigpen, A.E.; Davis, D.L.; Gautier, T.; Imperato-McGinley, J.; Russell, D.W. Brief report: The molecular basis of steroid 5 alpha-reductase deficiency in a large Dominican kindred. N. Engl. J. Med. 1992, 327, 1216-1219. 
30. Uemura, M.; Tamura, K.; Chung, S.; Honma, S.; Okuyama, A.; Nakamura, Y.; Nakagawa H. Novel 5 alpha-steroid reductase (SRD5A3, type-3) is overexpressed in hormone-refractory prostate cancer. Cancer Sci. 2008, 99, 81-86.

31. Hu, G.X.; Lian, Q.Q.; Ge, R.S.; Hardy, D.O.; Li, X.K. Phthalate-induced testicular dysgenesis syndrome: Leydig cell influence. Trends Endocrin. Metab. 2009, 20, 139-145.

32. Zhao, B.; Hu, G.X.; Chu, Y.; Jin, X.; Gong, S.; Akingbemi, B.T.; Zhang, Z.; Zirkin, B.R.; Ge, R.S. Inhibition of human and rat 3beta-hydroxysteroid dehydrogenase and 17 beta-hydroxysteroid dehydrogenase 3 activities by perfluoroalkylated substances. Chem. Biol. Interact. 2010, 188, 38-43.

33. Abdellatif, A.G.; Preat, V.; Vamecq, J.; Nilsson, R.; Roberfroid, M. Peroxisome proliferation and modulation of rat liver carcinogenesis by 2,4-dichlorophenoxyacetic acid, 2,4,5trichlorophenoxyacetic acid, perfluorooctanoic acid and nafenopin. Carcinogenesis 1990, 11, 1899-1902.

34. Jensen, A.A.; Leffers, H. Emerging endocrine disrupters: perfluoroalkylated substances. Int. J. Androl. 2008, 31, 161-169.

35. Johnson, J.D.; Gibson, S.J.; Ober, R.E. Cholestyramine-enhanced fecal elimination of carbon-14 in rats after administration of ammonium [14C] perfluorooctanoate or potassium [14C] perfluorooctanesulfonate. Fundam. Appl. Toxicol. 1984, 4, 972-976.

36. Giesy, J.P.; Kannan, K. Perfluorochemical surfactants in the environment. Environ. Sci. Technol. 2002, 36, 146A-152A.

37. Olsen, G.W.; Mair, D.C.; Church, T.R.; Ellefson, M.E.; Reagen, W.K.; Boyd, T.M.; Herron, R.M.; Medhdizadehkashi, Z.; Nobiletti, J.B.; Rios, J.A.; et al. Decline in perfluorooctanesulfonate and other polyfluoroalkyl chemicals in American Red Cross adult blood donors, 2000-2006. Environ. Sci. Technol. 2008, 42, 4989-4995.

38. Chengelis, C.P.; Kirkpatrick, J.B.; Myers, N.R.; Shinohara, M.; Stetson, P.L.; Sved, D.W. Comparison of the toxicokinetic behavior of perfluorohexanoic acid (PFHxA) and nonafluorobutane-1-sulfonic acid (PFBS) in cynomolgus monkeys and rats. Reprod. Toxicol. 2009, 27, 400-406.

39. Olsen, G.W.; Gilliland, F.D.; Burlew, M.M.; Burris, J.M.; Mandel, J.S.; Mandel, J.H. An epidemiologic investigation of reproductive hormones in men with occupational exposure to perfluorooctanoic acid. J. Occup. Environ. Med. 1998, 40, 614-622.

40. Gilliland, F.D.; Mandel, J.S. Mortality among employees of a perfluorooctanoic acid production plant. J. Occup. Med. 1993, 35, 950-954.

41. Biegel, L.B.; Liu, R.C.; Hurtt, M.E.; Cook, J.C. Effects of ammonium perfluorooctanoate on Leydig cell function: In vitro, in vivo, and ex vivo studies. Toxicol. Appl. Pharmacol. 1995, 134, 18-25.

42. Shi, Z.; Zhang, H.; Liu, Y.; Xu, M.; Dai, J. Alterations in gene expression and testosterone synthesis in the testes of male rats exposed to perfluorododecanoic acid. Toxicol. Sci. 2007, 98, 206-215.

43. Zhao, B.; Chu, Y.; Hardy, D.O.; Li, X.K.; Ge, R.S. Inhibition of 3beta- and 17beta-hydroxysteroid dehydrogenase activities in rat Leydig cells by perfluorooctane acid. J. Steroid. Biochem. Mol. Biol. 2010, 118, 13-17.

44. Kohn, M.C.; Parham, F.; Masten, S.A.; Portier, C.J.; Shelby, M.D.; Brock, J.W.; Needham, L.L. Human exposure estimates for phthalates. Environ. Health Perspect. 2000, 108, A440-A442. 
45. Binder, P.S.; Baumgartner, S.D.; Zavala, E.Y.; Deg, J.K.; Grossman, K.R. Refractive keratoplasty: Myopic keratomileusis in baboons. Curr. Eye Res. 1984, 3, 1187-1197.

46. Boxmeer, J.C.; Smit, M.; Weber, R.F.; Lindemans, J.; Romijn, J.C.; Eijkemans, M.J.; Macklon, N.S.; Steegers-Theunissen, R.P. Seminal plasma cobalamin significantly correlates with sperm concentration in men undergoing IVF or ICSI procedures. J. Androl. 2007, 28, 521-527.

47. Ge, R.S.; Chen, G.R.; Tanrikut, C.; Hardy, M.P. Phthalate ester toxicity in Leydig cells: Developmental timing and dosage considerations. Reprod. Toxicol. 2007, 23, 366-373.

48. Albro, P.W.; Corbett, J.T.; Schroeder, J.L.; Jordan, S.; Matthews, H.B. Pharmacokinetics, interactions with macromolecules and species differences in metabolism of DEHP. Environ. Health Perspect. 1982, 45, 19-25.

49. Albro, P.W.; Chapin, R.E.; Corbett, J.T.; Schroeder, J.; Phelps, J.L. Mono-2-ethylhexyl phthalate, a metabolite of di-(2-ethylhexyl) phthalate, causally linked to testicular atrophy in rats. Toxicol. Appl. Pharmacol. 1989, 100, 193-200.

50. Howdeshell, K.L.; Furr, J.; Lambright, C.R.; Rider, C.V.; Wilson, V.S.; Gray, L.E., Jr. Cumulative effects of dibutyl phthalate and diethylhexyl phthalate on male rat reproductive tract development: Altered fetal steroid hormones and genes. Toxicol. Sci. 2007, 99, 190-202.

51. Creasy, D.M.; Beech, L.M.; Gray, T.J.; Butler, W.H. The ultrastructural effects of di-n-pentyl phthalate on the testis of the mature rat. Exp. Mol. Pathol. 1987, 46, 357-371.

52. Gray, T.J.; Gangolli, S.D. Aspects of the testicular toxicity of phthalate esters. Environ. Health Perspect. 1986, 65, 229-235.

53. Sjoberg, P.; Bondesson, U.; Gray, T.J.; Ploen, L. Effects of di-(2-ethylhexyl) phthalate and five of its metabolites on rat testis in vivo and in vitro. Acta Pharmacol. Toxicol. (Copenh). 1986, 58, 225-233.

54. Gray, T.J.; Beamand, J.A. Effect of some phthalate esters and other testicular toxins on primary cultures of testicular cells. Food Chem. Toxicol. 1984, 22, 123-131.

55. Gray, T.J.; Butterworth, K.R. Testicular atrophy produced by phthalate esters. Arch. Toxicol. Suppl. 1980, 4, 452-455.

56. Sharpe, R.M. Hormones and testis development and the possible adverse effects of environmental chemicals. Toxicol. Lett. 2001, 120, 221-232.

57. Akingbemi, B.T.; Hardy, M.P. Oestrogenic and antiandrogenic chemicals in the environment: Effects on male reproductive health. Ann. Med. 2001, 33, 391-403.

58. Zhang, Y.; Lin, L.; Cao, Y.; Chen, B.; Zheng, L.; Ge, R.S. Phthalate levels and low birth weight: A nested case-control study of Chinese newborns. J. Pediatr. 2009, 155, 500-504.

59. Foster, P.M.; Thomas, L.V.; Cook, M.W.; Walters, D.G. Effect of DI- $n$-pentyl phthalate treatment on testicular steroidogenic enzymes and cytochrome P-450 in the rat. Toxicol. Lett. 1983, 15, 265-271.

60. Hallmark, N.; Walker, M.; McKinnell, C.; Mahood, I.K.; Scott, H.; Bayne, R.; Coutts, S.; Anderson, R.A.; Greig, I.; Morris, K.; et al. Effects of monobutyl and di(n-butyl) phthalate in vitro on steroidogenesis and Leydig cell aggregation in fetal testis explants from the rat: comparison with effects in vivo in the fetal rat and neonatal marmoset and in vitro in the human. Environ. Health Perspect. 2007, 115, 390-396.

61. Stroheker, T.; Cabaton, N.; Nourdin, G.; Regnier, J.F.; Lhuguenot, J.C.; Chagnon, M.C. Evaluation of anti-androgenic activity of di-(2-ethylhexyl)phthalate. Toxicology 2005, 208, 115-121. 
62. Loganathan, S.N.; Kannan, K. Occurrence of bisphenol a in indoor dust from two locations in the eastern United States and implications for human exposures. Arch. Environ. Contam. Toxicol. 2011, 61, 68-73.

63. Calafat, A.M.; Kuklenyik, Z.; Reidy, J.A.; Caudill, S.P.; Ekong, J.; Needham, L.L. Urinary concentrations of bisphenol A and 4-nonylphenol in a human reference population. Environ. Health Perspect. 2005, 113, 391-395.

64. Calafat, A.M.; Ye, X.; Wong, L.Y.; Reidy, J.A.; Needham, L.L. Exposure of the U.S. population to bisphenol A and 4-tertiary-octylphenol: 2003-2004. Environ. Health Perspect. 2008, 116, 39-44.

65. Ouchi, K.; Watanabe, S. Measurement of bisphenol A in human urine using liquid chromatography with multi-channel coulometric electrochemical detection. J. Chromatogr. B 2002, 780, 365-370.

66. Takeuchi, T.; Tsutsumi, O. Serum bisphenol a concentrations showed gender differences, possibly linked to androgen levels. Biochem. Biophys. Res. Commun. 2002, 291, 76-78.

67. Kuiper, G.G.; Lemmen, J.G.; Carlsson, B.; Corton, J.C.; Safe, S.H.; van der Saag, P.T.; van der Burg, B.; Gustafsson, J.A. Interaction of estrogenic chemicals and phytoestrogens with estrogen receptor beta. Endocrinology 1998, 139, 4252-4263.

68. Sohoni, P.; Sumpter, J.P. Several environmental oestrogens are also anti-androgens. J. Endocrinol. 1998, 158, 327-339.

69. Akingbemi, B.T.; Sottas, C.M.; Koulova, A.I.; Klinefelter, G.R.; Hardy, M.P. Inhibition of testicular steroidogenesis by the xenoestrogen bisphenol A is associated with reduced pituitary luteinizing hormone secretion and decreased steroidogenic enzyme gene expression in rat Leydig cells. Endocrinology 2004, 145, 592-603.

70. Murono, E.P.; Derk, R.C.; de Leon, J.H. Differential effects of octylphenol, 17beta-estradiol, endosulfan, or bisphenol A on the steroidogenic competence of cultured adult rat Leydig cells. Reprod. Toxicol. 2001, 15, 551-560.

71. Zhou, W.; Liu, J.; Liao, L.; Han, S. Effect of bisphenol A on steroid hormone production in rat ovarian theca-interstitial and granulosa cells. Mol. Cell. Endocrinol. 2008, 283, 12-18.

72. Ye, L.; Zhao, B.; Hu, G.; Chu, Y.; Ge, R.S. Inhibition of human and rat testicular steroidogenic enzyme activities by bisphenol A. Toxicol. Lett. 2011, 207, 137-142.

73. Niwa, T.; Fujimoto, M.; Kishimoto, K.; Yabusaki, Y.; Ishibashi, F.; Katagiri, M. Metabolism and interaction of bisphenol A in human hepatic cytochrome P450 and steroidogenic CYP17. Biol. Pharm. Bull. 2001, 24, 1064-1067.

74. Rodriguez-Bernaldo de Quiros, A.; Paseiro-Cerrato, R.; Pastorelli, S.; Koivikko, R.; Simoneau, C.; Paseiro-Losada, P. Migration of photoinitiators by gas phase into dry foods. J. Agric. Food Chem. 2009, 57, 10211-10215.

75. Nashev, L.G.; Schuster, D.; Laggner, C.; Sodha, S.; Langer, T.; Wolber, G.; Odermatt, A. The UV-filter benzophenone-1 inhibits 17beta-hydroxysteroid dehydrogenase type 3: Virtual screening as a strategy to identify potential endocrine disrupting chemicals. Biochem. Pharmacol. 2010, 79, 1189-1199.

76. Gray, L.E., Jr.; Ostby, J.; Ferrell, J.; Sigmon, R.; Cooper, R.; Linder, R.; Rehnberg, G.; Goldman, J.; Laskey, J. Correlation of sperm and endocrine measures with reproductive success in rodents. Prog. Clin. Biol. Res. 1989, 302, 193-206; discussion 206-199. 
77. Akingbemi, B.T.; Ge, R.S.; Klinefelter, G.R.; Gunsalus, G.L.; Hardy, M.P. A metabolite of methoxychlor, 2,2-bis(p-hydroxyphenyl)-1,1,1-trichloroethane, reduces testosterone biosynthesis in rat leydig cells through suppression of steady-state messenger ribonucleic acid levels of the cholesterol side-chain cleavage enzyme. Biol. Reprod. 2000, 62, 571-578.

78. Murono, E.P.; Derk, R.C. The reported active metabolite of methoxychlor, 2,2-bis(phydroxyphenyl)-1,1,1-trichloroethane, inhibits testosterone formation by cultured Leydig cells from neonatal rats. Reprod. Toxicol. 2005, 20, 503-513.

79. Matthews, J.; Celius, T.; Halgren, R.; Zacharewski, T. Differential estrogen receptor binding of estrogenic substances: A species comparison. J. Steroid Biochem. Mol. Biol. 2000, 74, 223-234.

80. Murono, E.P.; Derk, R.C. The effects of the reported active metabolite of methoxychlor, 2,2bis(p-hydroxyphenyl)-1,1,1-trichloroethane, on testosterone formation by cultured Leydig cells from young adult rats. Reprod. Toxicol. 2004, 19, 135-146.

81. Tsujita, M.; Ichikawa, Y. Substrate-binding region of cytochrome P-450SCC (P-450 XIA1). Identification and primary structure of the cholesterol binding region in cytochrome P-450SCC. Biochim. Biophys. Acta 1993, 1161, 124-130.

82. Bhosle, N.B.; Garg, A.; Jadhav, S.; Harjee, R.; Sawant, S.S.; Venkat, K.; Anil, A.C. Butyltins in water, biofilm, animals and sediments of the west coast of India. Chemosphere 2004, 57, 897-907.

83. Ohno, S.; Nakajima, Y.; Nakajin, S. Triphenyltin and Tributyltin inhibit pig testicular 17betahydroxysteroid dehydrogenase activity and suppress testicular testosterone biosynthesis. Steroids 2005, 70, 645-651.

84. McVey, M.J.; Cooke, G.M. Inhibition of rat testis microsomal 3beta-hydroxysteroid dehydrogenase activity by tributyltin. J. Steroid Biochem. Mol. Biol. 2003, 86, 99-105.

85. Lo, S.; Allera, A.; Albers, P.; Heimbrecht, J.; Jantzen, E.; Klingmuller, D.; Steckelbroeck, S. Dithioerythritol (DTE) prevents inhibitory effects of triphenyltin (TPT) on the key enzymes of the human sex steroid hormone metabolism. J. Steroid Biochem. Mol. Biol. 2003, 84, 569-576.

86. Doering, D.D.; Steckelbroeck, S.; Doering, T.; Klingmuller, D. Effects of butyltins on human 5alpha-reductase type 1 and type 2 activity. Steroids 2002, 67, 859-867.

87. Kano, Y.; Natori, S. Change in free amino acids and phospholipids in the head of adult Sarcophaga peregrina with age. Differentiation 1983, 24, 9-12.

88. Rao, K.S.; Burek, J.D.; Murray, F.J.; John, J.A.; Schwetz, B.A.; Bell, T.J.; Potts, W.J.; Parker, C.M. Toxicologic and reproductive effects of inhaled 1,2-dibromo-3-chloropropane in rats. Fundam. Appl. Toxicol. 1983, 3, 104-110.

89. Shemi, D.; Marx, Z.; Kaplanski, J.; Potashnik, G.; Sod-Moriah, U.A. Testicular damage development in rats injected with dibromochloropropane (DBCP). Andrologia 1988, 20, 331-337.

90. Potashnik, G.; Yanai-Inbar, I.; Sacks, M.I.; Israeli, R. Effect of dibromochloropropane on human testicular function. Isr. J. Med. Sci. 1979, 15, 438-442.

91. Egnatz, D.G.; Ott, M.G.; Townsend, J.C.; Olson, R.D.; Johns, D.B. DBCP and testicular effects in chemical workers: An epidemiological survey in Midland, Michigan. J. Occup. Med. 1980, 22, 727-732.

92. Potashnik, G.; Yanai-Inbar, I. Dibromochloropropane (DBCP): An 8-year reevaluation of testicular function and reproductive performance. Fertil. Steril. 1987, 47, 317-323. 
93. Chayoth, R.; Kaplanski, J.; Sror, U.; Shemi, D.; Shaked, I.; Potashnik, G.; Sod-Moriah, U.A. The effect of dibromochloropropane (DBCP) on in vitro cyclic AMP levels and testosterone production in rat testes. Andrologia 1988, 20, 232-237.

94. Heindel, J.J.; Berkowitz, A.S.; Kyle, G.; Luthra, R.; Bruckner, J.V. Assessment in rats of the gonadotoxic and hepatorenal toxic potential of dibromochloropropane (DBCP) in drinking water. Fundam. Appl. Toxicol. 1989, 13, 804-815.

95. Leone, M.; Costa, M.; Capitanio, G.L.; Palmero, S.; Prati, M.; Leone, M.M. Dibromochloropropane (DBCP) effects on the reproductive function of the adult male rat. Acta Eur. Fertil. 1988, 19, 99-103.

96. Sod-Moriah, U.A.; Shemi, D.; Potashnik, G.; Kaplanski, J. Age-dependent differences in the effects of 1,2-dibromo-3-chloropropane (DBCP) on fertility, sperm count, testicular histology and hormonal profile in rats. Andrologia 1990, 22, 455-462.

97. Kelce, W.R.; Raisbeck, M.F.; Ganjam, V.K. Gonadotoxic effects of 2-hexanone and 1,2-dibromo3 -chloropropane on the enzymatic activity of rat testicular 17 alpha-hydroxylase/C17,20-lyase. Toxicol. Lett. 1990, 52, 331-338.

98. Shivanandappa, T.; Krishnakumari, M.K. Hexachlorocyclohexane-induced testicular dysfunction in rats. Acta Pharmacol. Toxicol. (Copenh). 1983, 52, 12-17.

99. Dalsenter, P.R.; Faqi, A.S.; Webb, J.; Merker, H.J.; Chahoud, I. Reproductive toxicity and tissue concentrations of lindane in adult male rats. Hum. Exp. Toxicol. 1996, 15, 406-410.

100. Traina, M.E.; Rescia, M.; Urbani, E.; Mantovani, A.; Macri, C.; Ricciardi, C.; Stazi, A.V.; Fazzi, P.; Cordelli, E.; Eleuteri, P.; et al. Long-lasting effects of lindane on mouse spermatogenesis induced by in utero exposure. Reprod. Toxicol. 2003, 17, 25-35.

101. Ronco, A.M.; Valdes, K.; Marcus, D.; Llanos, M. The mechanism for lindane-induced inhibition of steroidogenesis in cultured rat Leydig cells. Toxicology 2001, 159, 99-106.

102. Walsh, L.P.; Stocco, D.M. Effects of lindane on steroidogenesis and steroidogenic acute regulatory protein expression. Biol. Reprod. 2000, 63, 1024-1033.

103. Suwalsky, M.; Villena, F.; Marcus, D.; Ronco, A.M. Plasma absorption and ultrastructural changes of rat testicular cells induced by lindane. Hum. Exp. Toxicol. 2000, 19, 529-533.

104. Chowdhury, A.R.; Gautam, A.K. Steroidogenic impairment after lindane treatment in male rats. J. UOEH 1994, 16, 145-152.

105. Wango, E.O.; Onyango, D.W.; Odongo, H.; Okindo, E.; Mugweru, J. In vitro production of testosterone and plasma levels of luteinising hormone, testosterone and cortisol in male rats treated with heptachlor. Comp. Biochem. Physiol. C Pharmacol. Toxicol. Endocrinol. 1997, 118, 381-386.

106. Sircar, S.; Lahiri, P. Effect of lindane on mitochondrial side-chain cleavage of cholesterol in mice. Toxicology 1990, 61, 41-46.

107. Henry, M.J.; Sisler, H.D. Effects of sterol biosynthesis-inhibiting (SBI) fungicides on cytochrome P-450 oxygenations in fungi. Pestic. Biochem. Physiol. 1984, 22, 262-275.

108. Blystone, C.R.; Lambright, C.S.; Howdeshell, K.L.; Furr, J.; Sternberg, R.M.; Butterworth, B.C.; Durhan, E.J.; Makynen, E.A.; Ankley, G.T.; Wilson, V.S.; et al. Sensitivity of fetal rat testicular steroidogenesis to maternal prochloraz exposure and the underlying mechanism of inhibition. Toxicol. Sci. 2007, 97, 512-519. 
109. Blystone, C.R.; Furr, J.; Lambright, C.S.; Howdeshell, K.L.; Ryan, B.C.; Wilson, V.S.; Leblanc, G.A.; Gray, L.E., Jr. Prochloraz inhibits testosterone production at dosages below those that affect androgen-dependent organ weights or the onset of puberty in the male Sprague Dawley rat. Toxicol. Sci. 2007, 97, 65-74.

110. Ohlsson, A.; Ulleras, E.; Oskarsson, A. A biphasic effect of the fungicide prochloraz on aldosterone, but not cortisol, secretion in human adrenal H295R cells-Underlying mechanisms. Toxicol. Lett. 2009, 191, 174-180.

111. Akingbemi, B.T.; Braden, T.D.; Kemppainen, B.W.; Hancock, K.D.; Sherrill, J.D.; Cook, S.J.; He, X.; Supko, J.G. Exposure to phytoestrogens in the perinatal period affects androgen secretion by testicular Leydig cells in the adult rat. Endocrinology 2007, 148, 4475-4488.

112. Reinli, K.; Block, G. Phytoestrogen content of foods--a compendium of literature values. Nutr. Cancer 1996, 26, 123-148.

113. Svechnikov, K.; Supornsilchai, V.; Strand, M.L.; Wahlgren, A.; Seidlova-Wuttke, D.; Wuttke, W.; Soder, O. Influence of long-term dietary administration of procymidone, a fungicide with anti-androgenic effects, or the phytoestrogen genistein to rats on the pituitary-gonadal axis and Leydig cell steroidogenesis. J. Endocrinol. 2005, 187, 117-124.

114.Hu, G.X.; Zhao, B.H.; Chu, Y.H.; Zhou, H.Y.; Akingbemi, B.T.; Zheng, Z.Q.; Ge, R.S. Effects of genistein and equol on human and rat testicular 3beta-hydroxysteroid dehydrogenase and 17betahydroxysteroid dehydrogenase 3 activities. Asian J. Androl. 2010, 12, 519-526.

115. Hiipakka, R.A.; Zhang, H.Z.; Dai, W.; Dai, Q.; Liao, S. Structure-activity relationships for inhibition of human 5alpha-reductases by polyphenols. Biochem. Pharmacol. 2002, 63, 1165-1176.

116. Yu, Z.H.; Chan, H.C. Gossypol as a male antifertility agent-Why studies should have been continued. Int. J. Androl. 1998, 21, 2-7.

117. Waites, G.M.; Wang, C.; Griffin, P.D. Gossypol: Reasons for its failure to be accepted as a safe, reversible male antifertility drug. Int. J. Androl. 1998, 21, 8-12.

118. Gu, Y.; Lin, Y.C.; Rikihisa, Y. Inhibitory effect of gossypol on steroidogenic pathways in cultured bovine luteal cells. Biochem. Biophys. Res. Commun. 1990, 169, 455-461.

119. Cuellar, A.; Diaz-Sanchez, V.; Ramirez, J. Cholesterol side-chain cleavage and 11 betahydroxylation are inhibited by gossypol in adrenal cortex mitochondria. J. Steroid Biochem. Mol. Biol. 1990, 37, 581-585.

120.Hu, G.X.; Zhou, H.Y.; Li, X.W.; Chen, B.B.; Xiao, Y.C.; Lian, Q.Q.; Liang, G.; Kim, H.H.; Zheng, Z.Q.; Hardy, D.O.; et al. The (+)- and (-)-gossypols potently inhibit both 3betahydroxysteroid dehydrogenase and 17beta-hydroxysteroid dehydrogenase 3 in human and rat testes. J. Steroid Biochem. Mol. Biol. 2009, 115, 14-19.

Sample Availability: Samples of the compounds including nestorone are available from the authors.

(C) 2011 by the authors; licensee MDPI, Basel, Switzerland. This article is an open access article distributed under the terms and conditions of the Creative Commons Attribution license (http://creativecommons.org/licenses/by/3.0/). 